\title{
Metalinguistic tactics in the Hong Kong protest movement
}

Article

Accepted Version

Jones, R. H. and Chau, D. (2022) Metalinguistic tactics in the Hong Kong protest movement. Journal of Language and Politics, 21 (1). pp. 143-172. ISSN 1569-2159 doi: https://doi.org/10.1075/jlp.21017.jon Available at https://centaur.reading.ac.uk/99352/

It is advisable to refer to the publisher's version if you intend to cite from the work. See Guidance on citing.

To link to this article DOI: http://dx.doi.org/10.1075/jlp.21017.jon

Publisher: John Benjamins

All outputs in CentAUR are protected by Intellectual Property Rights law, including copyright law. Copyright and IPR is retained by the creators or other copyright holders. Terms and conditions for use of this material are defined in the End User Agreement.

\section{www.reading.ac.uk/centaur}

\section{CentAUR}

Central Archive at the University of Reading

Reading's research outputs online 
Jones, R. H. and Chau, D. (forthcoming). Metalinguistic tactics in the Hong Kong protest movement. Journal of Language and Politics.

\title{
Metalinguistic Tactics in the Hong Kong Protest Movement
}

\author{
Rodney H. Jones \\ University of Reading \\ Dennis Chau \\ Open University of Hong Kong
}

\begin{abstract}
This paper explores the metalinguistic tactics used by Hong Kong protesters in 2014 and 2019 and how they reflected and exploited a range of dominant ideologies about language in the city. These tactics are considered both in terms of their rhetorical utility in the "message war" between protesters and authorities, and their significance in the broader sociolinguistic context of Hong Kong. The analysis reveals how such tactics entailed both opportunities and risks, allowing protesters to create shareable discursive artifacts that spread quickly over social media and to promote in-group solidarity and distrust of their political opponents, but also limiting their ability to broaden the appeal of their messages to certain segments of the population and implicating them in upholding language ideologies that promote exclusion and marginalization.
\end{abstract}

Keywords: anti-languages, folk-linguistics, language ideologies, language mocking, metalanguage

\section{Introduction}

The period between 2014 — when pro-democracy protesters in Hong Kong occupied parts of the city for 82 days - and 2019 - a year marked by sometimes violent protests culminating in the enactment of the Hong Kong national security law-was a time of intense public debate, not just around issues of politics and governance, but around deeper issues of national and cultural identity. Debates about Hong Kong identity have a long history stretching back to before the transfer of sovereignty from Great Britain to China in 1997 (see e.g. Matthews 1997), and language has always been a key element in such debates, with the three main languages English, Cantonese, and Putonghua taking on different symbolic meanings at different points in Hong Kong's history. Cantonese, for example, has been variously regarded as a debased vernacular and a symbol of pride, English an emblem of success and a marker of outsider status, and Putonghua a practical tool for advancement and a threat to the city's cultural integrity (see e.g. Hansen-Edwards 2019a, b, Lai 2005, 2011, Pennington and Yue 1994).

"Language about language" - evaluative commentary about what language people use and how they use it - has been a staple of governmental, journalistic, and popular discourses in the city for the past half-century, from the "moral panics" around supposed declining levels of English in the 1980s and 1990s (Lin 1997) to more recent debates about "mainlandization" associated with the use of Putonghua (Hansen-Edwards 2019b). Metalanguage has long been a tool Hongkongers 
use to draw distinctions between themselves and outsiders, and among themselves (based on class, education, and in-group loyalty), and has often served political purposes, allowing Hongkongers to position themselves in relation to mainland Chinese, to "foreigners", and to other Hongkongers with different political affiliations. This was no less true during the protests of 2014-2019, when "language about language" was widely circulated both on the streets and over social media (Hansen-Edwards 2017).

This paper explores the tactical uses of metalinguistic discourse by protesters and examines how they exploited a range of attitudes about language that already existed in the city. It presents three case studies illustrating three different kinds of metalinguistic tactics: 1) language mocking, specifically the ridiculing of the linguistic practices of police officers, 2) linguistic obfuscation, the use of particular ways of speaking and writing ostensibly to evade surveillance by authorities, and 3) folk forensics, practices of analyzing the language of others in order to make claims about their place of origin and possible political affiliation. These tactics are considered both in terms of their rhetorical utility in the "message war" between protesters and authorities, and in terms of their broader socio-historical significance. The tactical use of metalanguage for political purposes in these case studies highlights how language ideologies and political ideologies are inevitably intertwined, and how the complex and volatile sociolinguistic environment in Hong Kong created both opportunities and risks for protesters deploying these tactics. The data for these case studies come from online forums and social media sites used by the protesters, from mainstream media, as well as from other discursive artifacts such as memes and protest signage.

\section{Metalinguistic tactics and political resistance}

Language has always played a central role in political protests, with protesters, governments and the press all deploying diverse linguistic resources to promote or undermine various political positions. Much of the work on the language of protest has focused on the rich repertoire of communicative practices associated with protest movements such as slogans, signs, pressstatements, and petitions (Tilly 2006), and more recently on the new communicative practices of resistance made possible by digital media (e.g. Tufekci 2018). At the same time, sociolinguists have become increasingly interested in the role of specific linguistic practices within these wider communicative genres, including code mixing and translanguaging, language play and metalinguistic commentary, and how these practices are used to promote particular political ideologies, demonstrate affiliation to different groups, claim political legitimacy, and contest the legitimacy of others.

The most obvious examples of language used as a tool in political protest are cases where language itself is the reason for protest, as in the pro-Cantonese protests in Guangzhou in 2010 (Gao 2012). In such cases, however, language rights are rarely the sole impetus for protest, language often serving as a proxy for broader projects of regional autonomy or minority rights. But even when language is not the central focus, protesters' language choice on signs and in other forms of communication can be used to symbolize political ideologies and to promote solidarity among protesters. Martín Rojo (2014), in her investigation of the 15-M protest movement in Spain, argues that the presence of underrepresented languages in the linguistic landscape of protests functioned as a form of symbolic capital. Similarly, observers of the Arab Spring protests in Egypt (Abolezz 2014, Panovic 2017) and Tunisia (Shiri 2015) have pointed out how protesters' use of vernacular Arabic (as well as other languages and scripts) helped them 
to claim a "revolutionary personae" and "advance processes of vernacularization ... as part of their political goals" (Panovic 2017, 233).

More directly relevant to this paper is the use of Cantonese by protesters in Hong Kong, particularly since the 2014 "Umbrella Movement". Lou and Jaworski (2016) see the frequent use of written Cantonese (as opposed to Standard Written Chinese) in the protest signage and art that decorated the protest zones as a way that protesters asserted their "unique" Hong Kong identities. They also document the strategic use of other linguistic codes, such as the French expression: "Soyez réaliste, demandez l'impossible" ('be realistic, demand the impossible') from the Mai 1968 student revolution in France, and the English quote from John Lennon's song "Imagine": "You may say I'm a dreamer but I'm not the only one", arguing that the use of foreign languages and references to foreign cultural products and historical protest movements "indexed the Hong Kong protesters as young but well educated, politically savvy and cosmopolitan” (615).

Lee and Chau (2018) make similar points about the relationship between code choice and political affiliation in their examination of the hashtags used by protesters and sympathizers on Instagram posts about the protests. They argue that the translingual practices found in those hashtags - combining written Cantonese, traditional Chinese characters (as opposed to the simplified characters used on the mainland), and Chinese characters mixed with English wordswere used to express unity and solidarity and to assert Hong Kong identity. In some cases, they observe, posters also used these resources in ways that demonstrated "insider knowledge" through, for example, deploying local slang expressions or making intertextual references to local events as a way of excluding non-Hongkongers.

In some cases the translanguaging practices of protesters themselves can constitute a form of political resistance against administrative, political and linguistic boundaries imposed by authorities. As Flores (2014) argues, translanguaging is inherently a political act. One example of this can be seen in the translingual practice of "Shitizen Chinglish" the deliberate creation by some Chinese internet users of new and subversive forms of English which, as Li (2016) argues, functions both as form of political protest and as a way of projecting a modern "metrolingual" aesthetic.

Another way language has been used in the service of political protest and dissent can be seen in political humour and satire which mocks or ridicules the linguistic practices of political adversaries or engages in various forms of language play. There is a long history of such tactics in dissident discourses in many societies (e.g. Dementyev 2009 in the Soviet Union, Herzfeld 2001 in contemporary Greece). Little (2017) argues that such tactics often depend for their humour on the very boundaries for acceptable language use that authorities have set up, an example of how tactics of resistance sometimes build upon and exploit structures of control.

Much political humour involves forms of mockery or ridicule directed towards authorities or political opponents in such a way that the humour simultaneously mitigates the "impoliteness" of the ridicule and makes it even more humiliating. Vladimirou and House (2018) refer to this form of ridicule as "ludic impoliteness", the use of a range of discursive strategies (such as imitation/stylization, juxtaposition, and intertextuality) to devalue the public image of a person or institution and render them a "vernacular spectacle" (p. 150). Such strategies, they argue, can be 
particularly effective in digital environments, setting off "trajectories of impoliteness" (p. 156) in which users work together to build upon one another's expressions of ridicule.

In China, examples of this can be seen in political jokes (Choy 2018) and comedic performances such as xiangsheng 'crosstalk', which in the late 1980s incorporated implicit critiques of government officials, sometimes through mocking the linguistic practices of the bureaucracy and state run media, and more recently, online xiangsheng performances, such as those of Guo Degang (郭德綱), who makes fun of government censorship policies using puns that invoke taboo topics (Moser 2018).

The Chinese internet has also been a site for the circulation of $e^{\prime} g a o$, online spoofs that often indirectly criticize government policy through puns and other forms of language play. Perhaps the most well-known example is a series of memes that circulated in the early 2000s featuring pictures of a fictional creature called the "grass mud horse" or căonímă (草泥馬) (a homophone for the phrase "fuck your mother"), who was said to be in constant battle with another creature, the “river crab" or héxiè (河蟹), a pun on the word for harmony héxié (和諧), a term used as part of the Chinese government jargon justifying internet censorship. Meng (2011) argues that such practices serve the dual function of criticizing government policies and creating feelings of solidarity among those who build upon one another's memetic creations.

Also relevant, though perhaps not so obviously connected to political protest, are the small, everyday acts of resistance people engage in against more immediate authority figures through humour and language mocking. An example particularly germane to our discussion is Lin's (2000) description of the way working-class schoolboys in Hong Kong engage in language mocking as a way of asserting their indigenous Cantonese identities and resisting the sociocultural dominance of English in the school curriculum.

Finally, political dissidents also employ tactics of linguistic obfuscation, altering existing linguistic forms in ways intended to make their communications more difficult for authorities to monitor. This is sometimes accomplished through the development of "secret codes" or underground argots, what Halliday (1976) refers to as "anti-languages". As with other linguistic tactics of dissent, obfuscation has a long history. In the 19th century, for instance, Marx and his contemporaries used underground languages along with parody and irony to "smuggle" their ideas past censors (Rose 1978).

More recently, tactics of obfuscation can be seen in dissident language online. Again, the Chinese internet provides a range of examples such as the use of homophones, the use of characters that look like other characters, and the use of graphical elements or pictures instead of words as ways of evading censors (Wozniak, 2015).

There are also examples of dissidents censoring their own words in order to present an implicit critique of censorship. Anthonissen (2003), for example, describes how South African newspapers responded to censorship in the 1980s by redacting (or "blacking out") phrases and sentences from their own articles, thus simultaneously implying the kinds of things they might criticize the government about and producing a parody of the practice of censorship. A similar tactic can be seen in the recent practice in Hong Kong of people creating "Lennon Walls" (walls 
covered with Post-it notes with pro-democracy messages popular during 2014-2019) with blank Post-it notes in response to the new national security law, thereby highlighting the restrictions on political expression they perceive the law has resulted in (Leung 2020).

In this paper we are concerned with how Hong Kong protesters deployed the kinds of metalinguistic tactics we have described above. The term metalinguistic tactics here refers to linguistic practices that are designed to call attention to language for the purpose of political resistance. The notion of metalanguage - language about language (Jakobson 1960) — has been employed to study different aspects of language use from grammar to pragmatics to issues of discourse and identity (Jaworski et al. 2012). It has often been employed in studies of language attitudes (e.g. Dorleijn and Nortier 2019, Karyolemou 1994), including attitudes expressed through metalinguistic discourse online (e.g. Aslan and Vásquez 2018, Lee 2013). The evaluative function of metalanguage is not always manifested in explicit judgements; it can take more implicit forms, including linguistic practices that indirectly reveal attitudes or evaluations such as code choice, stylization, and language play.

In using the word tactics we are invoking de Certeau's (1984) distinction between strategieswhich are employed within the organizational structures of authority — and tactics — which are defensive, opportunistic ways those outside of these structures attempt to seize momentary advantages, often by appropriating and adapting aspects of the very strategies that have been used to keep them in their place. Tactics are achieved by "poaching in countless ways on the property of others" (xii).

De Certeau's insights help to highlight the fact that the power of metalinguistic tactics to contest authoritative political ideologies often comes from the way they appropriate and adapt authoritative language ideologies, deeply held assumptions about how language works and the social values assigned to different languages and linguistic practices (Irvine and Gal 2000, Woolard and Schieffelin 1994). Language ideologies are themselves political, conferring power and prestige on particular groups based on their language use and marginalizing other groups (Gal and Woolard 1995). Ideologies associated with, for example, the "standard" language (Lippi-Green 1997) or notions of "linguistic purity" (Thomas 1991), often function as "battlegrounds on which broader debates over race, state, and nation are played out" (Blackledge 2012, 1).

How people use metalinguistic tactics for political purposes sometimes reveals their attitudes or "folk-ideas" about how language works and the status of different linguistic practices in their society (Preston 2012), beliefs that often reproduce the society's dominant language ideologies and advance the interests of dominant groups. Sometimes, however, the invocation of language ideologies in metalinguistic discourse is more opportunistic, appropriated in ways that are designed to call the legitimacy of dominant groups into question. This more opportunistic, tactical leveraging of language ideologies inevitably involves both opportunities and risks, allowing people who use such tactics to recruit the public's deep-seated beliefs about language in the service of their political messages, but at the same time sometimes strengthening the structures of domination to which these language ideologies ultimately contribute. 
The case studies in this paper illustrate metalinguistic tactics that primarily circulated online through social media sites and discussion forums. As others have noted, the protests of 20142019 in Hong Kong took place as much online as they did in physical spaces (see e.g. Jones and $\mathrm{Li}, 2016$ ), with social media functioning as "an insurgent public sphere" (Lee, So, and Leung 2015). This fact is important for understanding how these tactics were deployed and how they circulated. Because of the participatory architecture of online spaces, activists can use them not just to broadcast messages, but also to recruit others to share these messages with the hopes that they will "go viral". In this regard, the effectiveness of a particular tactic is a matter not just of whether or not it promotes the aims of the movement, but is also a matter of whether or not it facilitates the creation of shareable "discursive objects" (e.g. memes, catchphrases, conspiracy theories) that others willingly engage with, comment on, creatively rework, and distribute to others in the network.

While examples of the phenomena we will describe were circulated widely across multiple social media platforms, including Facebook, Instagram, WhatsApp, and Telegram, and in some instances taken up by mass media outlets, most of them are from LIHKG, a multi-category forum website sometimes referred to as "Hong Kong's Reddit", which was particularly popular with protesters. It began in 2014 as a third-party app connected to the HKGolden forum, became a separate forum in 2016, and was one of the main platforms used for discussing tactics during the "leaderless" anti-extradition protests in 2019.

\section{Language mocking}

The first example we will discuss is the tactic of language mocking. While there has been considerable work in sociolinguistics examining the mocking of the way other people talk as a form of racist discourse, used by more powerful groups to denigrate the less powerful (e.g. Hill 2008), mocking can also be a tool used by the less powerful to represent those in authority in unfavourable ways. Mocking how authority figures speak can sometimes serve to contrast their linguistic practices with the more vernacular practices of "ordinary people", thus portraying them as marginal or "out of touch". In some situations, however, as is the case we will consider here, this tactic works by turning authoritative language ideologies against authorities, by highlighting how their practices do not conform to what is considered proper, appropriate, or linguistically competent.

Of the numerous instances of protesters mocking the linguistic practices of police that went viral online during 2014-2019, perhaps the most iconic was that of Mr Steve Hui, the then Chief Superintendent in charge of the daily press briefing held at 4:00pm during the occupation actions of late 2014. Because many people distrusted the justifications for police actions offered at these briefings, Hui became a symbol among protesters of police prevarication and doublespeak. Rather than directly accusing Hui of lying, protesters deployed the tactic of mockery, treating the briefings like a regular TV entertainment programme, which they dubbed "4pm Hui Sir" and even setting up a fan page for him on Facebook which gained over 50,000 followers. The focus of the online commentary was usually not on what Hui Sir said, but how he said it, especially when it came to the English language summaries he provided for non-Cantonese-speaking journalists, which he always prefaced with the phrase "I will now recap in English". Commentators denigrated Hui's English, which exhibited phonological and grammatical features 
associated with Hong Kong English such as substituting /w/ for /v/, simplifying consonant clusters and deleting or overusing articles (Hung 2012).

In examples 1 and 2, taken from LIHKG, for instance, posters use "mock politeness" (Culpeper, 1996) to 'praise' Hui and his briefings, promoting them (in example 1) as opportunities for viewers to learn "Native English" (appropriating the language often used to promote language schools in Hong Kong), a suggestion made funnier by the fact that the appellation [surname]+Sir is used in Hong Kong not just for police officers, but also for male teachers. Similarly, the poster in example 2 declares Hui's English to be "superb" followed by two [sosad] emojis.

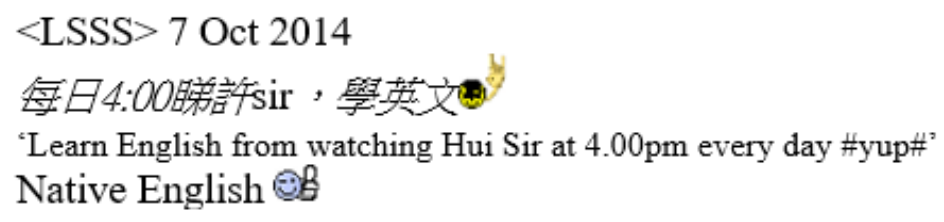

Example 1: LIHKG,7/10/2014(1)

$<$ YCLM $>7$ Oct 2014

許 $\mathrm{Sir}$ 英文好到呢察察

'Hui Sir's English is superb [sosad] [sosad]'

Example 2: LIHKG,7/10/2014(2)

Sometimes this mockery took the form of written stylizations of Hui Sir's English, as in example 3, where the poster imitates Hui Sir answering a question. And sometimes Hui Sir's English was evaluated through explicitly derogatory labels, as in example 4, where the poster refers to it as "Chinglish".

$<$ CGBD $>8$ Oct 2014

tha than thanQ YOUR QUESTION 슬

Example 3: LIHKG,8/10/2014(1)

$<$ Chingku $>8$ Oct 2014

許生英文好奞聽，係native chinglish speaker. [...]

'Mr Hui's English is unbearable. He's a native chinglish speaker.'

Example 4: LIHKG,8/10/2014(2)

As these instances of mocking, ridicule, and stylization spread across social media, Hui Sir's way of speaking, and its association with police more generally became "enregistered" (Agha 2003) to the point that it could be invoked simply with the catchphrase "I will now recap in English", which became a feature of internet memes as well as satire in magazines and on television. In figure 1, for instance, the catchphrase and Hui Sir saying in Cantonese “或者我重 
申"' ('Maybe I'll recap') are inserted into the famous “Keep Calm” meme. Figure 2 is a Facebook post featuring the cover of 100 毛 (100Most), a satirical magazine, with a picture of a local actor Hui Shiu-hung dressed up like Hui Sir and the headline: "4pm with Fong Chung Sir: How to clear up your love relationships" (a pun invoking the "clearance" of protest sites). The extract from the article pasted next to it contains advice about romantic relationships written in the bureaucratic style of Hui Sir's briefings, which ends with the words: "I will now recap in English". But, instead of providing an English translation, the poster types a series of ellipses and the words: "Translate Server Error", an expression used on social media in Hong Kong as a way of deriding others' English ability. The catchphrase even found its way to the protest sites, as can be seen in figure 3, a pro-democracy ultimatum written in chalk on the street "voiced" through Hui Sir's image and his catchphrase. In this case, it is unclear whether the non-standard features of the English version are a stylization of Hui Sir's English or - equally plausible - features of the English spoken by the protester who wrote it (see below for further discussion of this point).

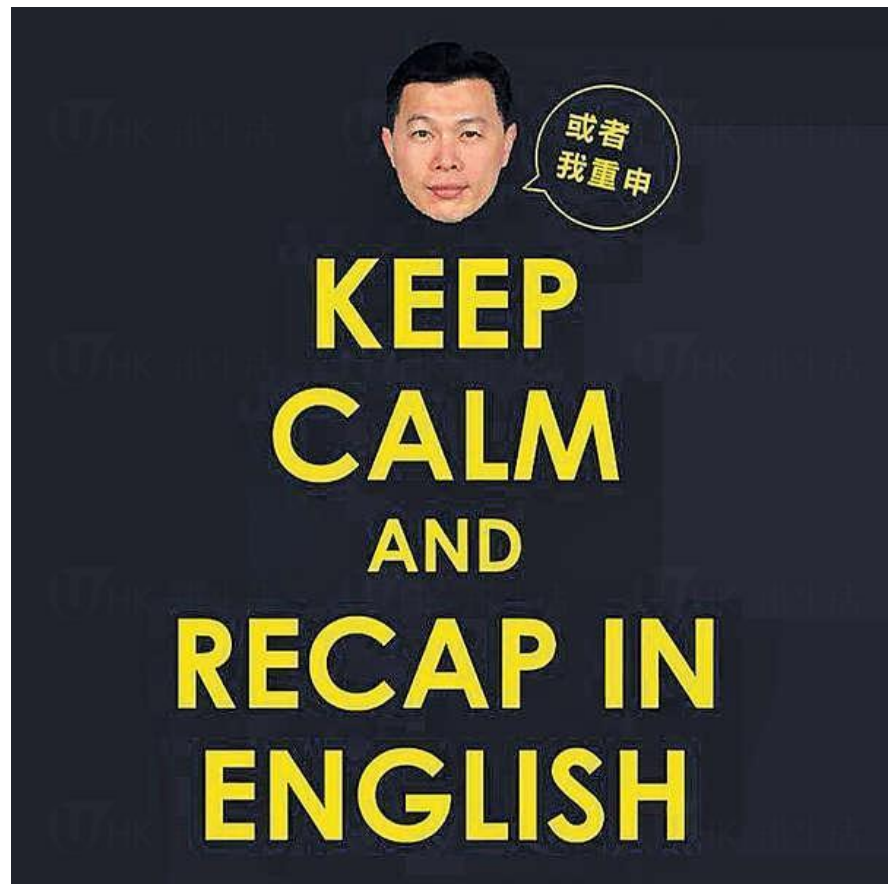

Figure 1: "Keep Calm" meme 


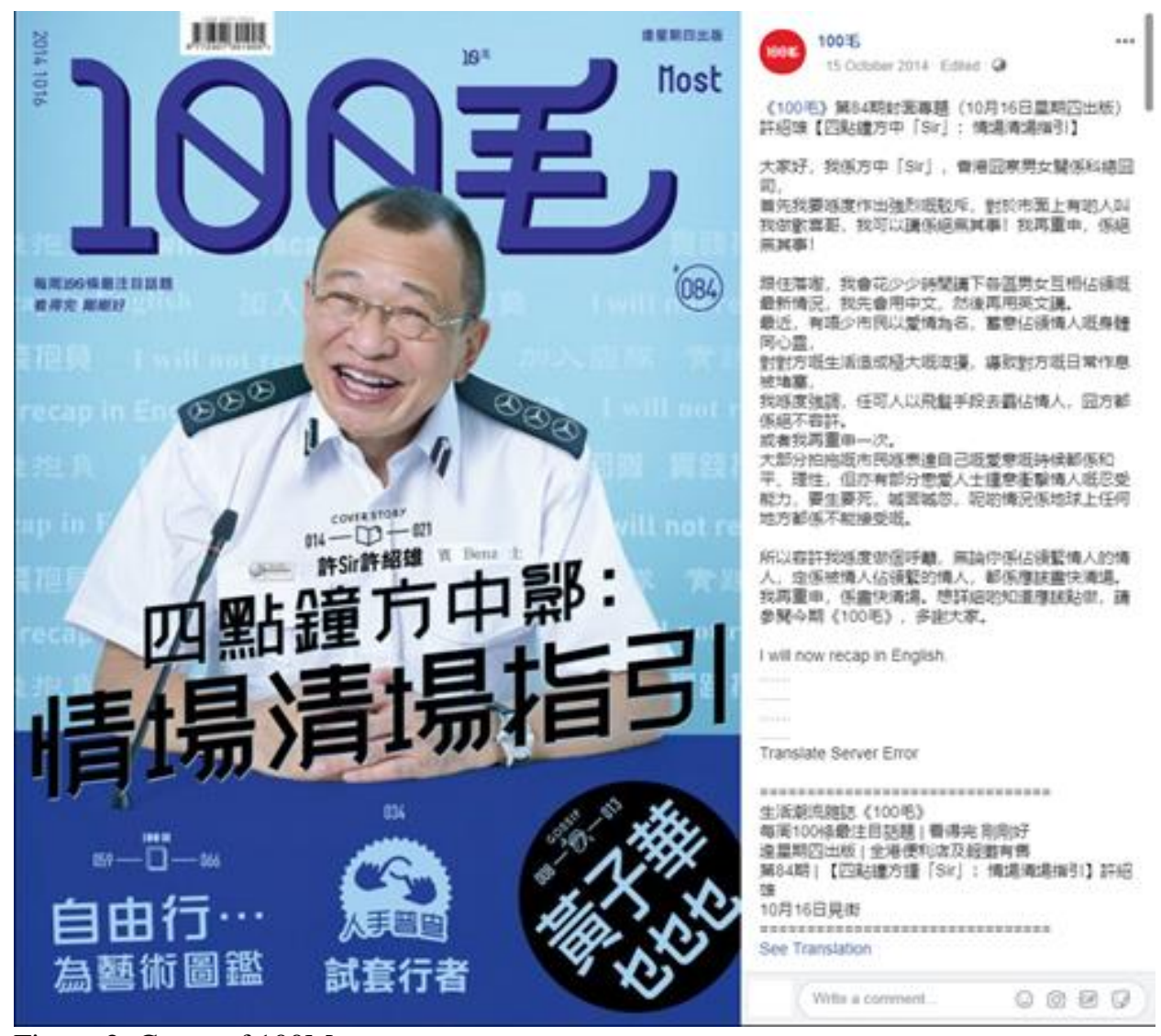

Figure 2: Cover of 100Most

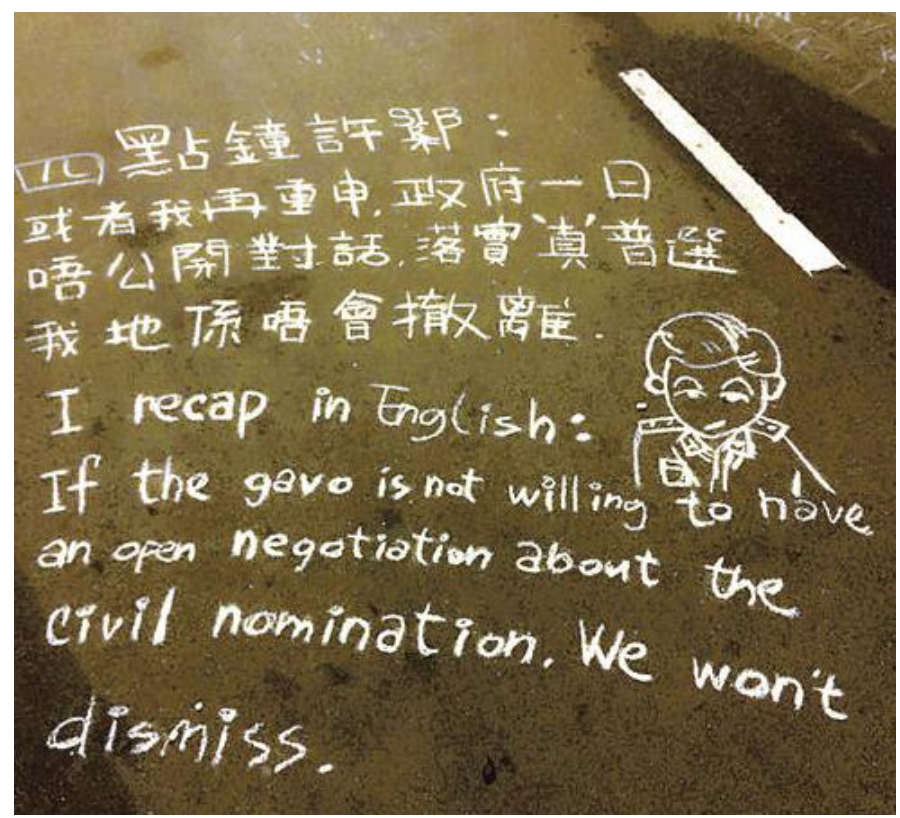

Figure 3: Chalk drawing at protest site

This memification of the mockery of Hui Sir's English demonstrates one potential advantage of this tactic: Humour and catchphrases are more likely to circulate online than more direct or discursive critiques, and this wide circulation of playful content not only helped to promote a 
negative image of the police, but also to promote a feeling of "conviviality" among the protesters sharing it (Varis and Blommaert 2015).

It is equally important, however, to consider the underlying messages protesters were sending with such mockery and how these messages drew upon broader language ideologies. In many of the posts, protesters were quite explicit about the associations they were drawing between English ability and issues of class and educational attainment, associations that reflect what Lin (2000) calls a "hierarchy of languages" in Hong Kong that has persisted since the colonial period, with English maintaining its place at the top of the hierarchy as an emblem of wealth, education, and sophistication even two decades after the end of colonial rule.

In example 5, for instance, the poster belittles Hui's academic achievement by insinuating that his English proficiency is comparable to that of a junior secondary school student, and that his undergraduate degree is inferior. In other posts users chararactize Hui, and police in general, as speaking "Yi Jin English", referring to an educational programme offered to low achievers.

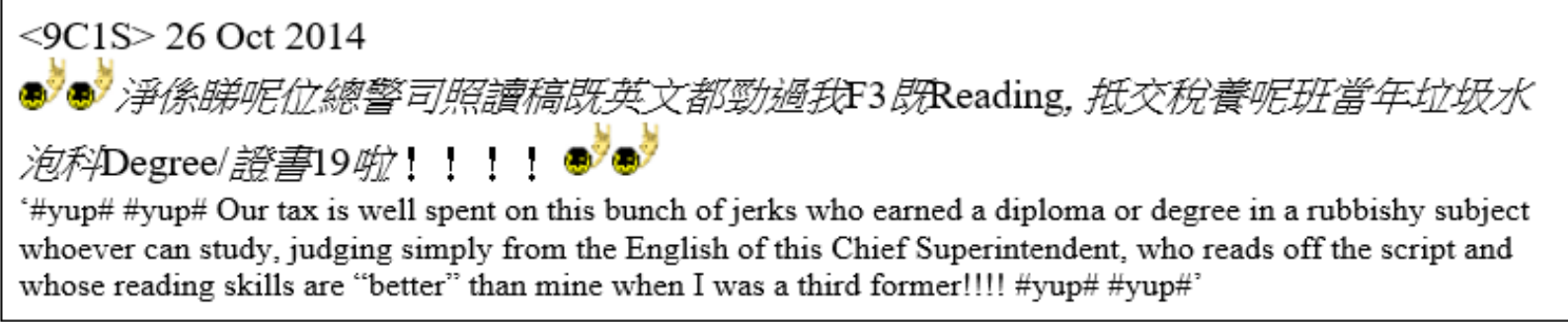

Example 5: LIHKG,26/10/2014

In such formulations, the invocation of low educational attainment is inevitably linked to class. In the same post, for example, the poster labels Hui "19", a vulgar Cantonese slang expression used to refer to self-important "low-class nobodies". In other posts, these attributions of "low class" status are further linked to particular activities and moral failings supposedly associated with "low class", "uneducated" people. In example 6, for instance, the poster juxtaposes the superintendent's "kindergarten broken English" with gambling and going to prostitutes.

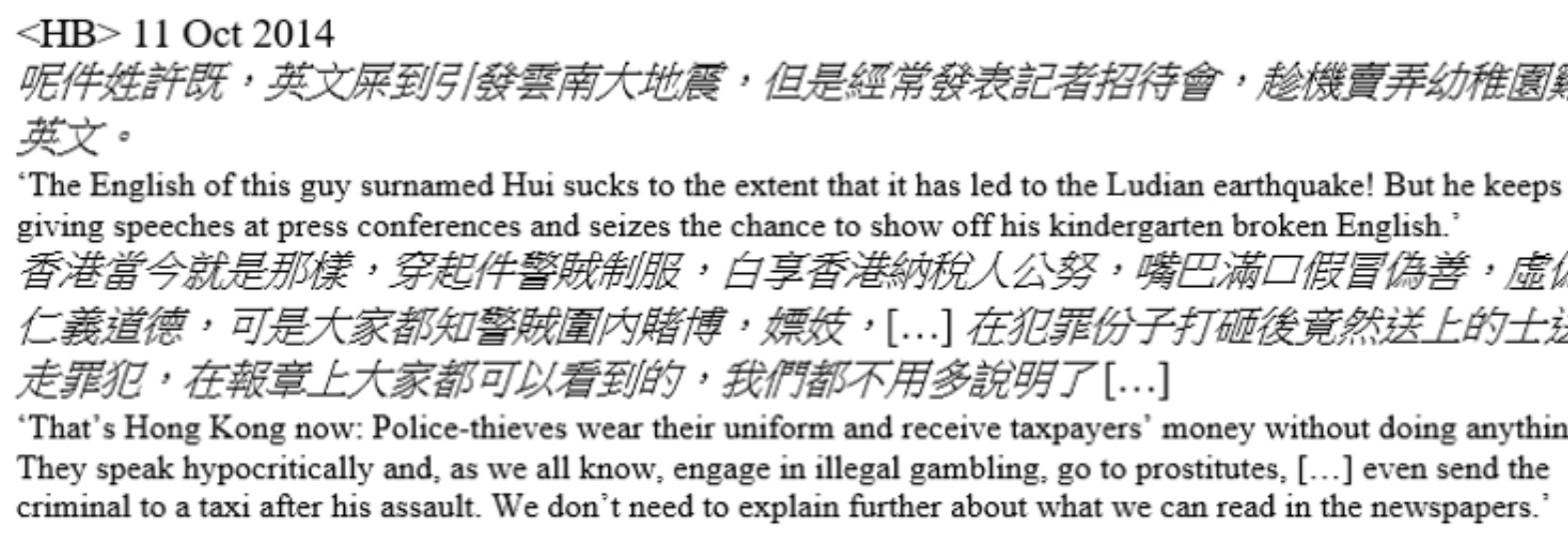

Example 6: LIHKG,11/10/2014 
Thus, the "poor English" of Hui and his colleagues served as a proxy not just for their lack of education, but for the dishonesty and corruption protesters associated with the police more generally. In Hui's case in particular, language mocking served to further discredit his official justifications for the use of police force against protesters during the briefings, justifications which protesters were already inclined to dismiss. By emphasizing what they see as the "broken English" these messages are delivered in, they further highlighted what they considered to be the "broken" status of the messages themselves, and the "broken" and "crooked" status of the messengers. This rhetorical move also advanced the implication that the police's aggressive measures to quell the protests (Cheng and Chan 2017) were the result not of careful planning, but of ignorance and unrestrained emotion.

Portraying the police as "low class", uneducated, and corrupt also created a foil against which protesters could advance a contrasting image of themselves as "young but well educated, politically savvy and cosmopolitan" (Lou and Jaworski 2016, 615). In this case, English came to be represented as a weapon that police did not have full possession of and that protesters could therefore use to potentially subvert their power.

At the same time, while this tactic aimed at subverting authority, its ability to do so depended upon its promotion of certain authoritative language ideologies which the students who were protesting were just as much subject to as the police they were criticizing. One of these is the ideology of "standardness", which holds that one particular variety of a language is more correct than others, and that deviation from the standard is essentially defective. In Hong Kong, exonormative models such as British and American English have long been taught in schools and held in high regard. There has also been much concern over the "falling standards" of English as a result of students' use of non-standard forms in schoolwork and in online writing (Lee 2007a). In fact, the group most frequently criticized for poor English in the society is not police officers, but students, most of whom find studying English to be a challenge (Evans and Green 2007). The fact is, the non-standard "Hong Kong English" used by Hui was not fundamentally different from that spoken by many of the protesters, including some key spokespeople of the movement. Perhaps the chance to make the "English standard" of others a target of derision, as opposed to being themselves targets of such derision, is one of the things that made this tactic viscerally satisfying. Nevertheless, in deploying it, protesters ended up promoting the very attitudes and beliefs about English that had likely been used against many of them in their academic studies.

Furthermore, in other circumstances, Hui's variety of Hong Kong English might be more positively evaluated. Bolton and Kwok (1990), for example, in a study of Hong Kong University students found that, when asked what variety of English they would like to speak, male students tended to prefer a "Hong Kong accent" over British and American accents, and among many there is an assumption that Hongkongers speaking English with a "standard" British or American accent are usually trying to "show off" (Jenks and Lee 2016). Hansen-Edwards (2016) in fact links a growth in positive attitudes towards Hong Kong English with the political protests of that period. And so, by embracing the standard language ideology to mock the police, protesters to some degree undermined their own claims to the authentic Hong Kong identity the movement celebrated. 
Finally, this tactic ran the risk of exasperating class divisions. In Hong Kong English has long been regarded as a "dominant symbolic resource" (Lin 1996, 53) that differentiates the middle class from the working class. By reinforcing the class hierarchies associated with English, protesters risked reinforcing a dominant narrative promoted at the time by authorities that the movement pitted "spoiled" and "privileged" students against honest working-class Hongkongers whose livelihoods had been jeopardized by the occupations (Sataline 2014). Similarly, this tactic also risked exacerbating the generational divide between protesters and their parents (Wang 2019), many of whom may not have been proficient English speakers.

\section{Linguistic obfuscation}

The second tactic we will consider is linguistic obfuscation, explicit attempts by groups of speakers to alter their language to make it less comprehensible to out-group members. As Halliday (1976) points out in his examination of "anti-languages", the real function of such ostensible attempts at secrecy is not always to exclude outsiders, but to fulfill certain social functions within the in-group such as building feelings of solidarity and communicating to the out-group that they are excluded, even in cases in which are actually able to decipher the "secret messages" of the in-group.

The example in this section comes from the summer of 2019 when street protests against the proposed extradition bill ${ }^{1}$ became increasingly violent, with police firing rubber bullets and bean bag rounds (one of which injured the eye of a female protester), discharging tear gas in enclosed spaces, and reportedly deploying undercover officers as agents-provocateur, and protesters staging a three-day sit-in at the airport during which they assaulted a tourist and a journalist who they accused of being mainland "spies". The Civil Human Rights Front called for a rally in Victoria Park on August 18 to denounce police brutality.

The day before the rally, a LIHKG user initiated a discussion thread written in Romanized Cantonese entitled "[8.18] TAI DUC MING NGO KONG MUD YEA GEH, YUP LAI" ("[8.18] Come here if you understand what I am saying'). While Cantonese-English bilinguals in Hong Kong occasionally write some words in Romanized Cantonese in online communication (e.g. Lee 2007b), and Romanization is a feature of new and playful forms of online communication that developed around the time of the protests, such as 'Kongish' (Hansen-Edwards 2016, Li et al. 2020), communication using almost exclusively Romanized Cantonese is by no means common. But in example 7, the poster suggests protesters adopt this writing practice in order to make their communication incomprehensible to "spies". Over subsequent days, the practice spread through the forum and across other social media platforms.

\footnotetext{
${ }^{1}$ The Fugitive Offenders and Mutual Legal Assistance in Criminal Matters Legislation (Amendment) Bill 2019
} 


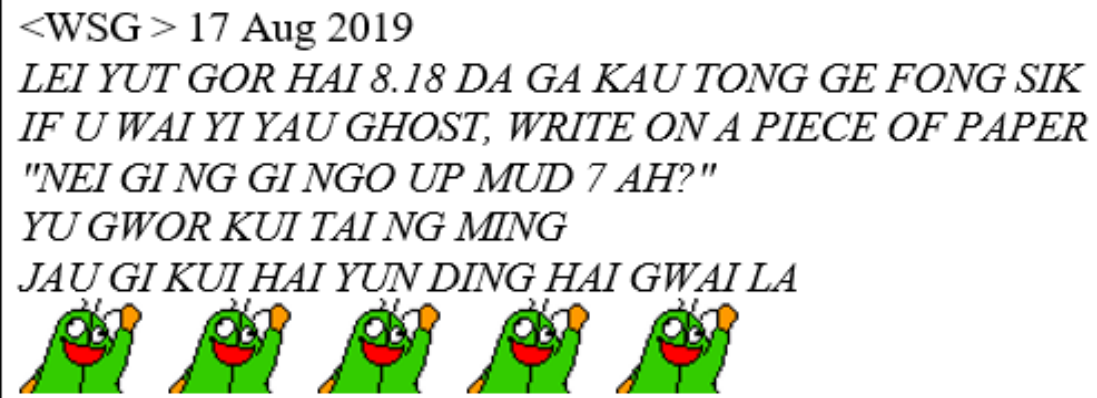

TONG NGO TUI BAO KUI AH DIU!!!!!!!!

'This is how we are going to communicate during the protest on $18 \mathrm{Aug}$.

If you suspect there is a spy, write "nei gi ng gi ngo up mud 7 ah?" ("Do you understand what the heck I am talking about?') on a piece of paper.

If the person can't get it, you know the answer.

Fuck - do bump this post for me!'

Example 7: LIHKG,17/08/2019(1)

The key theme that ran through the messages of posters adopting this practice was the idea that it would confuse mainlanders who were supposedly monitoring protesters' communication. In one of the many responses to the original thread (example 8), another poster expresses the hope that using the so-called "gongnui Ping yum" ('Kong Girl pinyin') can help them get rid of police stalking their posts and members of the so-called "50 cents" brigades, mainland Chinese citizens who are paid 50 cents each for posting pro-Chinese comments on social media.

$<$ NGNJM $>17$ Aug 2019

Gee chi whole lihk dou yung gongnui Ping yum

Mon Po dog tung 5 cents collect skin

'Feeling quite proud that $\mathrm{LIHK}(\mathrm{G})$ uses Kong Girl pinyin as well.

Time to get lost, police stalking our posts and 50 cents!'

Example 8: LIHKG,17/08/2019(2)

Shortly after the thread was initiated, the practice spread to other media. Figure 4 , for example, a headline from the Apple Daily, renders the movement's slogan "Liberate Hong Kong, revolution of our times" as: GWONG FUK HEUNG GONG, SI DOI GAK MING, adding, "8.18 WAI DOR LEI AH GUNG YUEN HEUNG GONG YAN DOU SI GIN", meaning "August 18 Victoria Park, see you there Hongkongers." Figure 5 is a poster issued by Amnesty International, reading " $W O$ PING JAAP WUI, NGO YAU KUEN. V PARK NO SPACE GUM DIM SIN", meaning "I have the right for a peaceful assembly. What are we supposed to do if there's no room in Victoria Park?" 


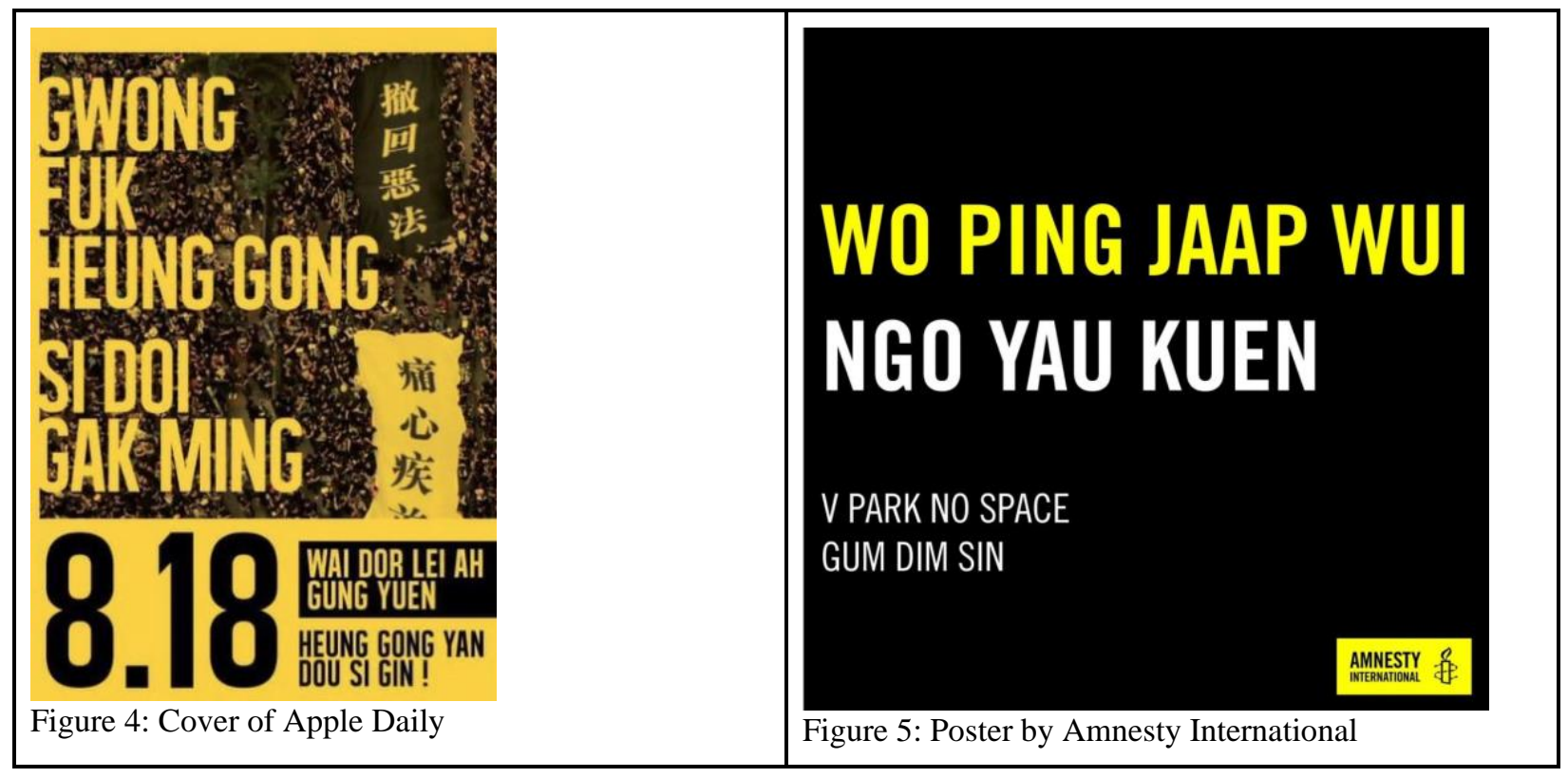

Finally, as with the language mocking described in Section 3, this metalinguistic tactic, which began online, found its way onto the streets, with protesters at the August 18 rally and subsequent ones displaying signs in Romanized Cantonese such as that pictured in figure 6, which says "HEUNG GONG YAN YIU JAANG HEI GA YAU" ('Hongkongers, hold our heads high, add oil' 2 )

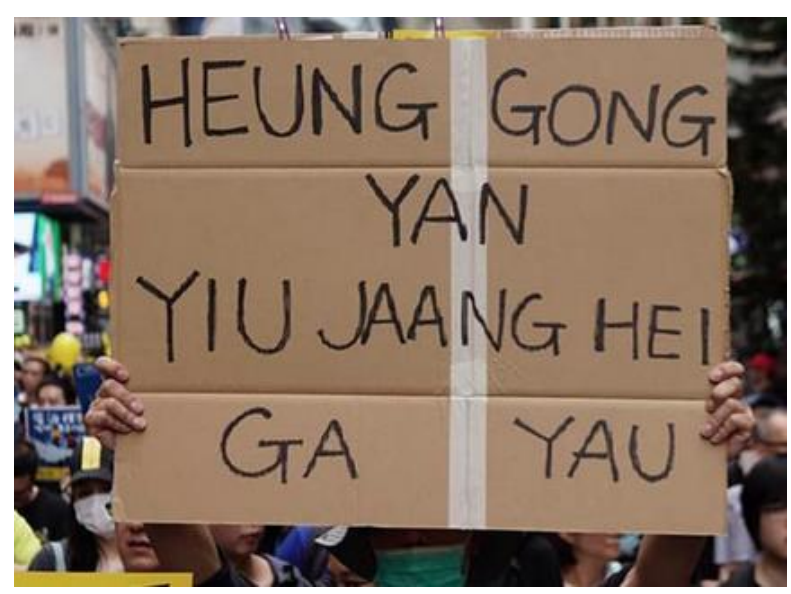

Figure 6: Sign in Romanized Cantonese

One of the most important features of this Romanization is how "haphazard" and playful it is, following none of the previously developed standardized systems for Romanizing Cantonese (e.g. Yale, Meyer-Wempe, Jyutping) and sometimes playfully incorporating English phrases (e.g. "if u wai yi yau ghost, write on a piece of paper" in example 7), English transliterations of Cantonese slang (e.g. "dog" for the Cantonese slang for police 狗, and "collect skin" for the Cantonese expression 收皮 'to tell somebody to get lost' in example 8), and “sinified” English phrases (e.g. "V Park no space" in Figure 5). The lack of standardization is not surprising given

\footnotetext{
2 “Add oil” (加油) is a Chinese expression meaning “keep it up” or “don’t give up”
} 
that, unlike pupils on the mainland, Hongkongers do not learn a system for Romanizing Chinese in school. That is not to say the spellings are random. Since the late 1990s, Hong Kong netizens have been developing their own conventions for Romanizing Cantonese, often incorporating English words and phrases, which they alter and adapt as they see fit (Lee 2007a,b). In this respect, the Romanized Cantonese in these messages is better viewed not as a "code", but as a "translanguaging practice" ( $\mathrm{Li}$ et al. 2020) built up and sustained by a community of users over time.

More recently, practices of mixing English and Romanized Cantonese that transcend traditional boundaries between named languages have become more mainstream as a way of expressing pride in Hongkonger's unique way of speaking and signaling opposition both to the official language policy of the government and the increasing influence of Putonghua (Hansen-Edwards 2016). What is different in the way Romanized Cantonese and other translingual practices such as "Kongish" were deployed during the protests and their earlier uses in internet communication was the explicit framing of these practices as "anti-languages", ways of communicating which do not just strengthen in-group solidarity, but exclude the out-group members, a framing also seen in the metalanguage around "Kongish". For instance, the "Our Story" section of the Kongish Daily ${ }^{3}$ Facebook page warns readers: "Only knowing English or Cantonese ng wui give you the full picture, you have to be a Hongkonger sin can fully understand our page, Kongish Daily :))."

As a vehicle for the passing of "secret messages" among protesters, however, this form of ad hoc Romanization has obvious deficiencies. As the poster in example 9 rightly points out, even many Hongkongers have difficulty understanding this writing, and some associate it with "Martian language", a term used to refer to various forms of Chinese "netspeak". Another problem, as the poster in example 10 points out, is that Romanized Cantonese is likely to be just as comprehensible to local police officers (referred to here as "Yi Jin boys", see above) as it is to protesters.

$<$ BS $>17$ Aug 2019

but ping yum dou ng hai gor gor hker tai duc ming ga wor $\sim$ kui dei wa li $\mathrm{d}$ hai for sing mun

'But not every Hongkonger knows how to read pinyin. They say it is Martian language.'

Example 9: LIHKG,17/08/2019(3)

$<$ C-problem $>17$ Aug 2019

Ngai chun jai ng sik ping yum meh?

Yau meh yung?

'Don't Yi Jin boys know pinyin?

How useful is it?"

Example 10: LIHKG,17/08/2019(4)

3 https://www.facebook.com/KongishDaily/ 
The rather obvious flaws of Romanized Cantonese as a "secret code" belie the fact that its primary purpose was not really to make messages indecipherable to "spies" but to build solidarity among users and strengthen their shared Hongkonger identity. In example 11, for instance, the poster shares the LIHKG thread on her Facebook page and invites specifically "heung gong yan" ('Hongkongers') to "bump" ('share') the post. In this case, the act of sharing is more metapragmatic than pragmatic (Blommaert 2015), less about actually promoting the practice and more about claiming a loyal "heung gong yan" identity.

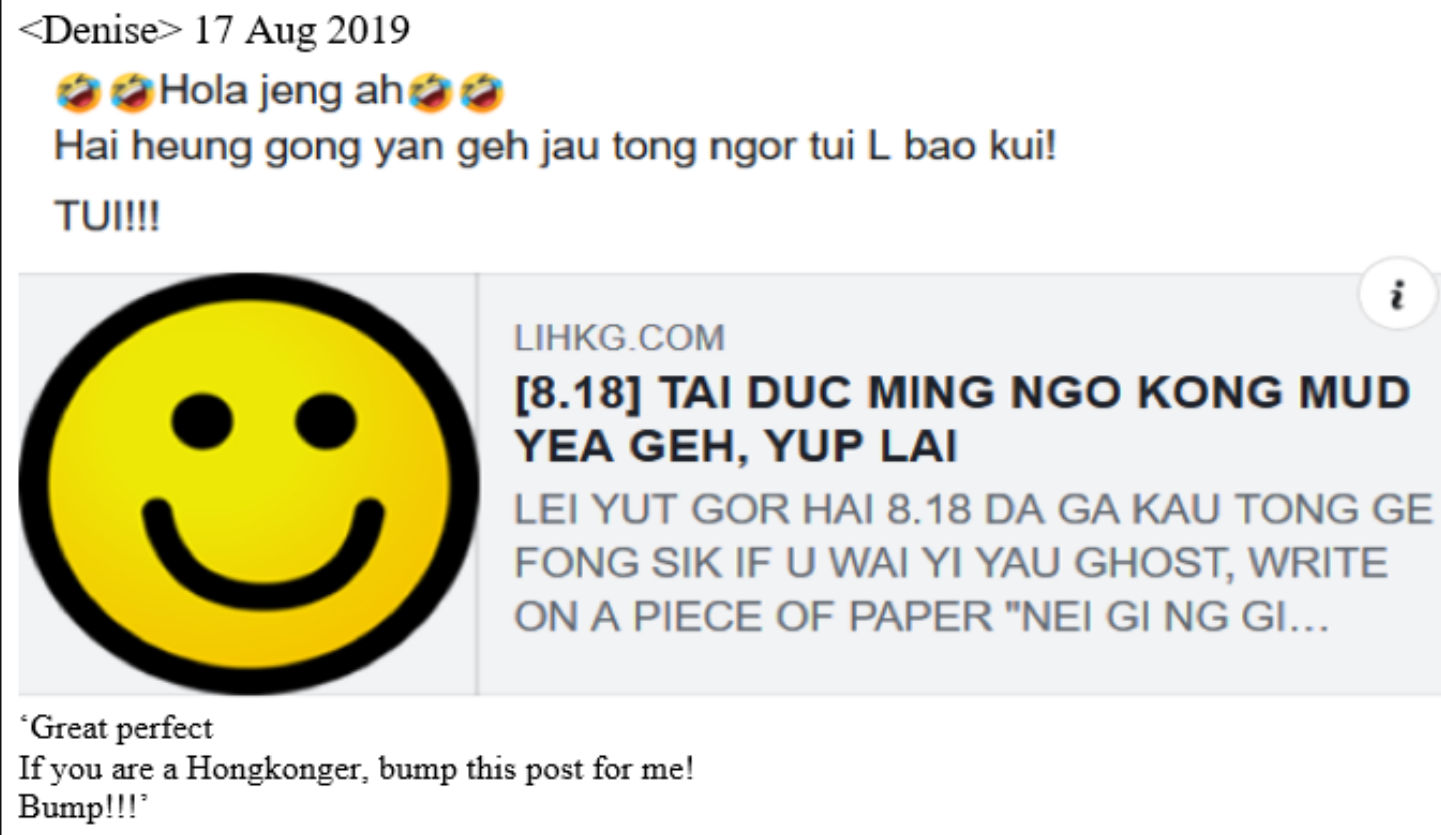

Example 11: Facebook,17/08/2019

Similarly, in example 12, in a Facebook post, the Ming Pao Weekly, a major entertainment magazine, inserts into its brief report of a demonstration the Romanized Cantonese sentence "HEUNG GONG YAN GA YAU, MING CHAU TUNG NEI DEI YAT CHAI HANG" ('Hongkongers add oil. MP Weekly walks with you all!') as a way of demonstrating solidarity with the protesters. 


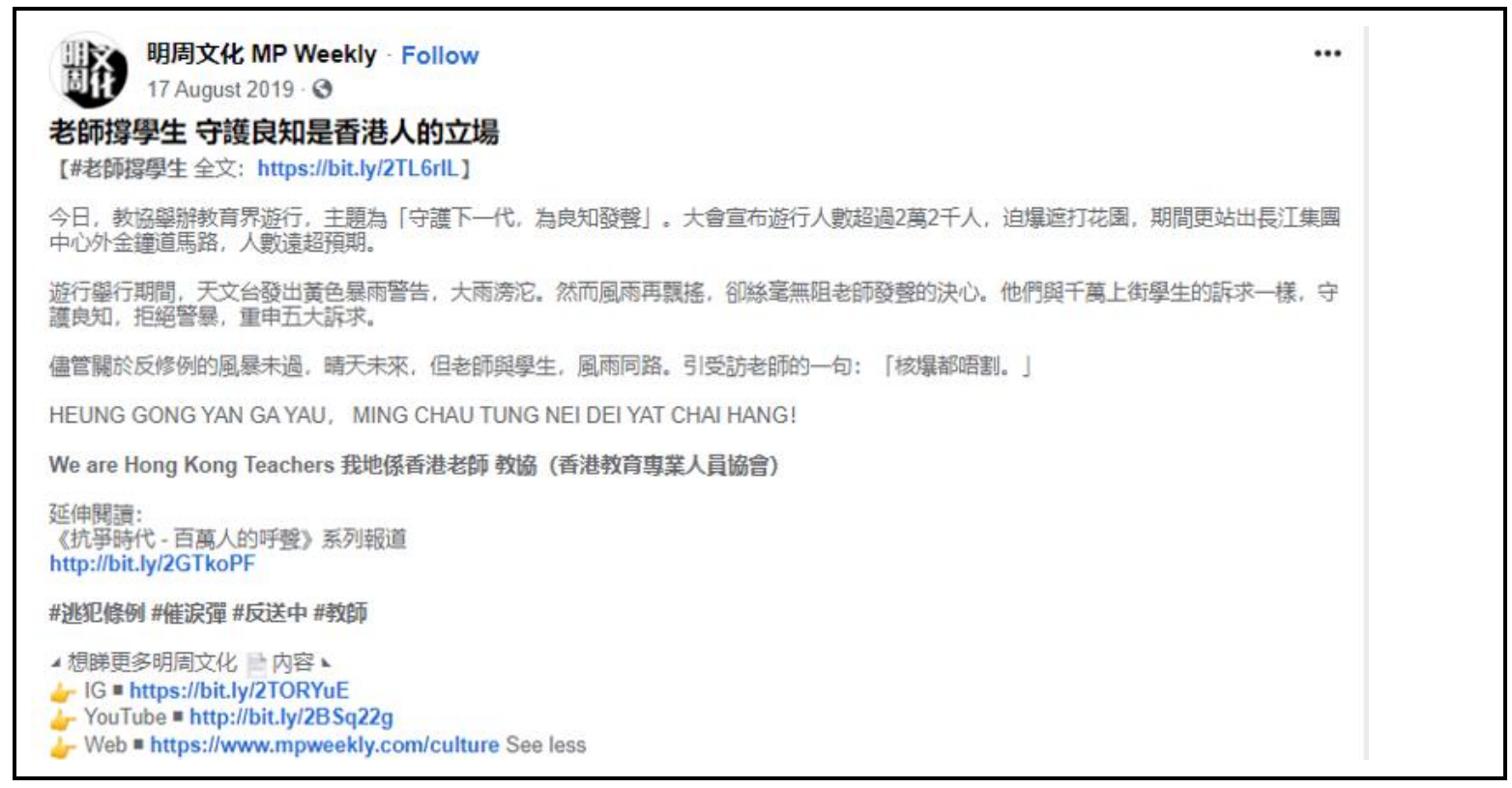

Example 12: Facebook,17/08/2019(2)

In fact, the lack of standardization and the challenge involved in deciphering messages written in this way (even for "real" Hongkongers), is part of what helped to build among users a sense of belonging, by engaging them in a creative game of improvised encoding and decoding. The ludic nature of this practice not only helped to create what Li Wei (2011) calls "translanguaging space", a space where language users build social practices and identities that transcend the constraints of authoritative language ideologies, but also provided the opportunity for the creation of shareable discursive artifacts with the potential to quickly circulate over digital networks. Such practices, however, are not only "fun" and "engaging", but also often political, representing a challenge to established social orders. Li and Zhu (2019) have coined the term "playful subversion" to refer to the flouting of rules and conventions with the aim of challenging and subverting the status quo.

At the same time, such tactics are not without risks. It is inevitable that linguistic tactics designed to claim the status of particular linguistic practices as markers of in-group loyalty end up promoting the marginalization of people with different practices; "anti-languages", by their nature, are "othering discourses" (Palfreyman 2005). The tactic of subverting the authoritative language ideologies upon which the official language policy of the Hong Kong government is based (summed up in the phrase 兩文三語—two writing systems (Chinese and English) —and three forms of spoken language (Cantonese, Putonghua, and English), a policy that erases the differences between written Cantonese and Standard Written Chinese) is also at odds with other tactics for promoting the legitimacy of Cantonese that have adopted a kind of "strategic essentialism", emphasizing the connection between Cantonese and written Chinese, its status as a "regional lingua franca", and international status as "a language not a dialect" (Gao 2012).

\section{Folk forensics}

The last case study focuses on a phenomenon we are calling "folk forensics", the ways people use their everyday "folk" beliefs about language (Niedzielski and Preston 2003) as tools to "uncover" information about others such as where they are from and whether or not they are 
lying (Vrij 2008). Folk forensics is what people engage in when they explicitly examine the way people talk or write for 'clues' about their identity or intentions. When engaged in collectively, this practice is related to the wider phenomenon of conspiracy theorizing (Dentith 2018), and such practices are further facilitated by digital media, which allow ordinary people to share, replay, and dissect video or audio recordings of people's speech. Gies and Bortoluzzi (2014, 532) note that "online engagement with forensics amounts to a particularly intense form of participation" which possesses characteristics reminiscent of fan communities. Often the focus of these collaborations is the search for evidence to affirm already existing beliefs and suspicions of the group. As with the two metalinguistic tactics we have discussed, the most important aspect of this tactic seems to be not the accuracy of what is "uncovered", but the affinity with like-minded others that participation in this practice generates.

The large amount of amateur video generated in the Hong Kong protests and circulated on social media provided protesters with considerable material with which to "document" police abuses and contest official accounts of events. But as Jones and Li (2016) point out, the evidentiary status of these videos depended crucially on socially organized ways of attending to and analyzing what happened in these videos which developed in particular communities.

The example we will present here involved the analysis of the speech of a police officer preparing to carry out an operation at a shopping mall on August 5, 2019, a day when a citywide strike and multiple demonstrations were occurring. On that day, a 1.5-minute video ${ }^{4}$ was uploaded on the YouTube channel of CitizenNews (眾新聞) with the title “【8.5大埔】警方欲 進人大埔超級城被拒” (“[8.5 Tai Po] Police denied entry to Tai Po Mega Mall'). The video depicts a police officer arguing with a security guard who refused to permit entry to the mall. After a few moments, the officer gives up and orders his colleagues to assemble in preparation to move to another location. Example 13 is an excerpt from the comments section of the YouTube page.

\footnotetext{
${ }^{4}$ https://www.youtube.com/watch?v=CLr4j7tNJjE
} 


\section{LT}

\section{講普通話的港察?}

'A Putonghua speaking Hong Kong police officer?'

$\mathrm{MC}$

[0:37 喂局态們] 香港警察會咁叫同僚, 第一聽。公安扮警察落黎香港執法, 一開 $\square$ 就穿䍃。

'[0:37 Hey comrades] It's the first time I've heard that Hong Kong police would call each other in this way. (He's from) the Chinese security force coming to Hong Kong and masquerading as a policeman for law enforcement. His identity was exposed as soon as he talked.'

\section{KC Chan}

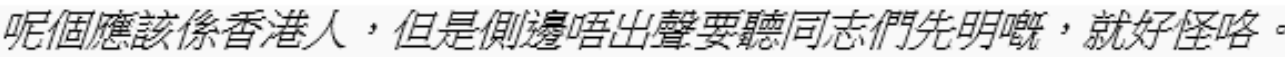

"This guy should be a Hongkonger, but those around him who could only understand "comrades" are strange."

\section{CC-477}

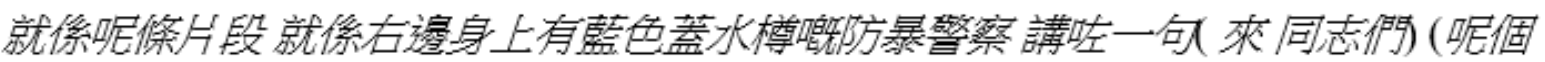
就係疑似中國大陸北方口音的人因為一時之間轉唔到/channel) […]

"That's the clip. The riot police officer carrying a bottle of water with a blue cap on his right uttered "Come, comrades." He was the guy with a suspected mainland northern Chinese accent who couldn't switch his language in time?

Example 13: YouTube comments

In the first comment, LT raises the question of if (or why) the officer is speaking Putonghua, the Chinese variety spoken on the mainland and official language of the Chinese state ("A Putonghua speaking Hong Kong police officer?"). In subsequent comments, other users affirm this suspicion and offer more detailed evidence. MC draws viewers' attention to a particular point in the video (0:37) where he asserts that the officer says: “Hey, comrades" (喂同志們) in Putonghua, and offers this as evidence that the officer is a member of the mainland security forces "masquerading" as a local police officer. What is significant here is not just the identification of the officer's speech as Putonghua, but the focus on the politically charged word "comrades", with its associations with the Communist Party of China. The singling out of this word calls into question not just the officer's place of origin, but also his political affiliation. This is followed by KC Chan offering an alternative theory: i.e., that while the officer himself may not be from the mainland, he is using Putonghua to communicate to suspected nonCantonese-speaking team members, a theory that expands the suspicion from a single officer to the entire group. Finally, CC-477 expands his assessment of the officer's speech to assert that he has a "northern Chinese accent", though he offers no further evidence to support this. 
Another YouTube video was posted shortly afterwards entitled “絕密片段: 香港警察講普通 話, 疑似非本地人士混人 | 20190805" 5 (“Top secret: Hong Kong police speaking Putonghua. Suspected non-local infiltration | 20190805') on a “localist” channel called 高清本土台 ('High Definition Local Channel'). The video begins with a voiceover introducing the background of the incident and inviting viewers to decide whether the officer in question was an "official" Hong Kong police officer (“正式取錄嘅香港警察”), echoing a question President Xi Jinping once asked a local police officer born on the mainland on his visit to Hong Kong, a phrase subsequently appropriated by protesters to question the loyalty of police officers. This is followed by a replaying of the suspicious segment of the original video (in which the officer supposedly used the word "comrades" in Putonghua) eight times. The commenter then asks the audience whether "tóngzhimen" is an expression commonly used by the police force, or in Hong Kong in general, before adding another layer to the analysis, asserting that the officer pauses after uttering the suspicious word and suggesting that this hesitation was evidence that he was switching "channels" (codes).

Whether or not the officer is actually speaking Putonghua is not really the issue here, and there are plenty of reasons to doubt this conclusion: At this point in the video, the officer is facing away from the camera, his voice is muffled by his helmet, and there is considerable ambient noise. Nevertheless, while this analysis may not represent good forensic practice, it is typical of the "improvised expertise" (Dentith 2018, 199) of conspiratorial reasoning in which an overall predisposition to believe something works in conjunction with processes of making salient particular details or semantic cues (Gebauer et al. 2016). It is, in fact, this process of finding details that "fit in" with already existing beliefs that makes conspiratorial reasoning so engaging, and helps make this video into a shareable artifact.

More important is the way protesters used this tactic to support a larger narrative about the supposed "infiltration" of the Hong Kong police force by members of the People's Liberation Army or the People's Armed Police, a conspiracy theory widely circulated during the protests both in 2014 and 2019, and one which invoked broader fears of "mainlandization" that have grown in Hong Kong since the return of sovereignty to China (Chen and Szeto 2017).

Like the tactics of mocking and obfuscation, a key function of these collective practices of folk forensics was the strengthening of in-group solidarity and the "othering" of out-group members. As Varis $(2019,4)$ notes, "conspiracy theorising is not only "about consolidating perceived pieces of evidence to form - for those involved - a coherent theory of the social world, but also about claims to privileged identities, and elite positions as those 'in the know"'. Ultimately, conspiratorial thinking is not just a cognitive phenomenon, but an interactional accomplishment with social and political functions, including managing intergroup relations and "challeng[ing] dominant ideological assumptions about social hierarchy and political legitimacy" (Sapountzis and Condor 2013, 731). In this case, the process of people coming together not just to comment on but to dissect and analyze the language of others functions as a tool for claiming in-group status.

${ }^{5}$ https://www.youtube.com/watch?v=HFbVZ8nt81Y 
But also like the other two tactics discussed above, folk forensics promotes authoritative language ideologies based on practices of inclusion and exclusion, specifically the ideas that 1) language is a reliable indicator of one's place of origin (or class, or educational status) and 2) the presence of "outsider" languages is a marker of "invasion" or "infiltration", an idea that has contributed to the marginalization of (and sometimes violence against) speakers of minority languages in societies all over the world, including Hong Kong (Gu 2011).

\section{Conclusion}

Folk linguistics and language attitudes research tends to focus on beliefs and attitudes about language as relatively stable characteristics of people and groups, and most discussions of language ideologies tend to focus on the way they serve the agendas of privileged segments of society. This paper has proposed an approach to language attitudes and ideologies that emphasizes their more performative nature through examining how metalinguistic tactics sometimes appropriate authoritative language ideologies in the service of political resistance. In this regard, rather than "metalanguage", it would be more appropriate to adopt Li and his colleagues' $(2020,325)$ term "metalanguaging", the dynamic, creative, translingual practices of commenting on language to fit the tactical demands of the moment.

Another important aspect of the tactics we have analyzed is the way they facilitated the creation of what Preston $(1996,60)$ refers to as "folk linguistic artifacts" that contain clear and unmistakable references to or imitations of particular linguistic practices, the intended symbolic characterization of which is immediately recognisable to the intended audience. Folk linguistic artifacts are not just durable carriers of language attitudes, but also provide opportunities for members to perform those attitudes in ways that claim in-group membership and impute outgroup membership on opponents - what Preston $(1996,60)$ calls the "performance potential" of folk linguistic artifacts. Finally, they also strengthen in-group solidarity through creating opportunities for members to engage in practices of collaborative creativity as they work together to create, revise, and recreate these artifacts. This was especially important in the context of the Hong Kong protests where much of the "message war" was conducted over social media, and depended on the creation of memetic discursive objects (in the form of catchphrases, "secret codes", and conspiracy theories) that could spread quickly over digital networks and encourage ludic engagement from other users.

At the same time, we have also pointed out some of the risks involved in these practices, in particular how, by appropriating authoritative language ideologies as a tool of resistance, the protesters ended up reinforcing forms of linguistic discrimination and marginalization that in some ways undermined the movement's messages of linguistic pride, tolerance, and inclusivity.

\section{References}

Aboelezz, Mariam. 2014. "The Geosemiotics of Tahrir Square: A Study of the Relationship between Discourse and Space.” Journal of Language and Politics 13 (4): 599-622.

Agha, Asif. 2003. "The Social Life of Cultural Value.” Language and Communication 23: 231273. 
Anthonissen, Christine. 2003. "Challenging Media Censoring: Writing Between the Lines in the Face of Stringent Restrictions.” In Discourse Approaches to Politics, Society and Culture (Vol. 8), ed. by James R. Martin, and Ruth Wodak, 91-112. Amsterdam: John Benjamins.

Aslan, Erhan, and Camilla Vásquez. 2018. “'Cash Me Ousside’: A Citizen Sociolinguistic Analysis of Online Metalinguistic Commentary." Journal of Sociolinguistics 22 (4): 406431.

Blackledge, Adrian. 2012. "Multilingualism and Ideology." In The Encyclopedia of Applied Linguistics, ed. by Carol Chapelle. Hoboken, New Jersey: Wiley-Blackwell.

Blommaert, Jan. 2015. "Meaning as a Nonlinear Effect: The Birth of Cool." AILA Review 28: 727. https://doi.org/10.1075/aila.28.01blo.

Bolton, Kingsley, and Helen Kwok. 1990. "The Dynamics of the Hong Kong Accent: Social Identity and Sociolinguistic Description.” Journal of Asian Pacific Communication 1 (1): 147-172.

Chen, Yun-Chung, and Mirana Szeto. 2017. "Reclaiming Public Space Movement in Hong Kong: From Occupy Queen's Pier to the Umbrella Movement." In City Unsilenced: Urban Resistance and Public Space in the Age of Shrinking Democracy, ed. by Jeffrey Hou, and Sabine Knierbein, 69-82. New York, NY: Routledge.

Cheng, Edmund W., and Wai-Yin Chan. 2017. "Explaining Spontaneous Occupation: Antecedents, Contingencies and Spaces in the Umbrella Movement." Social Movement Studies 16 (2): 222-239.

Choy, Howard Y.-F. 2018. "Laughable Leaders: A Study of Political Jokes in Mainland China." In Not Just a Laughing Matter: Interdisciplinary Approaches to Political Humor in China. ed. by King-fai Tam, and Sharon R. Wesoky, 97-115. Singapore: Springer.

Culpeper, Jonathan. 1996. "Towards an Anatomy of Impoliteness". Journal of Pragmatics 25 (3): 349-367.

de Certeau, Michel. 1984. The Practice of Everyday Life. Translated by Steven Rendall. Berkeley and Los Angeles: The University of California Press.

Dementyev, Vadim V. 2009. "Russian Anekdots of the 1970s: On the Material of the Soviet Humorous Journal 'Krokodil'.” Russian Journal of Communication 2 (3-4): 185-198.

Dentith, M. R. X. 2018. "Expertise and Conspiracy Theories.” Social Epistemology 32 (3):196208. https://doi.org/10.1080/02691728.2018.1440021.

Dorleijn, Margreet, and Jacomine Nortier. 2019. "Introduction." Applied Linguistics Review 10 (3): 281-291. https://doi.org/10.1515/applirev-2017-0048. 
Evans, Stephen, and Christopher Green. 2007. "Why EAP Is Necessary: A Survey of Hong Kong Tertiary Students.” Journal of English for Academic Purposes 6: 3-17.

Flores, Nelson. 2014. 'Let's Not Forget That Translanguaging Is a Political Act'. The Educational Linguist. https://educationallinguist.wordpress.com/2014/07/19/lets-not-forgetthat-translanguaging-is-a-political-act/ (April 8, 2021).

Gal, Susan, and Kathryn Woolard. 1995. "Constructing Languages and Publics: Authority and Representation.” Pragmatics 5 (2): 129-38.

Gao, Xuesong. 2012. “'Cantonese is not a Dialect': Chinese Netizens' Defence of Cantonese as a Regional Lingua Franca." Journal of Multilingual and Multicultural Development 33 (5): 449-464. https://doi.org/10.1080/01434632.2012.680461

Gebauer, Fabian, Marius H. Raab, and Claus-Christian Carbon. 2016. "Conspiracy Formation Is in the Detail: On the Interaction of Conspiratorial Predispositions and Semantic Cues: Conspiratorial Predispositions." Applied Cognitive Psychology 30 (6): 917-924. https://doi.org/10.1002/acp.3279.

Gies, Lieve, and Maria Bortoluzzi. 2014. "Purity and Contamination in Online Popular Forensics: Amateur-Expert Readings of the Meredith Kercher Murder Case." Continuum 28 (4): 532-544. https://doi.org/10.1080/10304312.2014.907871.

Gu, Mingyue. 2011. “'I Am not Qualified to Be a Hongkongese Because of My Accented Cantonese': Mainland Chinese Immigrant Students in Hong Kong." Journal of Multilingual and Multicultural Development 32 (6): 515-529.

Halliday, Michael A. K. 1976. “Anti-Languages.” American Anthropologist 78 (3): 570-584.

Hansen-Edwards, Jette G. 2016. "The Politics of Language and Identity: Attitudes towards Hong Kong English Pre and Post the Umbrella Movement.” Asian Englishes 18 (2): 157-164.

Hansen-Edwards, Jette G. 2017. "Language, Identity, and Politics in Hong Kong." Georgetown Journal of International Affairs, April 4, 2017.

https://www.georgetownjournalofinternationalaffairs.org/online-edition/language-identityand-politics-in-hong-kong.

Hansen-Edwards, Jette G. 2019a. The Politics of English in Hong Kong: Attitudes, Identity, and Use. Milton Park, Abingdon, Oxon: Routledge.

Hansen-Edwards, Jette G. 2019b. "'I Have to Save this Language, It's on the Edge Like an Endangered Animal': Perceptions of Language Threat and Linguistic Mainlandisation in Hong Kong." Journal of Multilingual and Multicultural Development 1-20. 
Herzfeld, Michael. 2001. "Irony and Power: Toward a Politics of Mockery in Greece." In Irony in Action: Anthropology, Practice, and the Moral Imagination, ed. by James Fernandez, and Mary Taylor Huber, 63-82. Chicago: University of Chicago Press.

Hill, Jane. 2008. The Everyday Language of White Racism. Oxford: Wiley-Blackwell.

Hung, Tony. 2012. "Hong Kong English.” In English in Southeast Asia: Features, Policy and Language in Use, ed. by Ee-Ling Low, and Azirah Hashim,113-133. Amsterdam: John Benjamins.

Irvine, Judith and Susan Gal. 2000. "Language Ideology and Linguistic Differentiation.” In Regimes of Language: Ideologies, Polities and Identities, ed. by Paul V. Kroskrity, 35-83. Santa Fe, NM: School of American Press.

Jakobson, Roman. 1960. "Linguistics and Poetics.” In Style in Language, ed. by Thomas E. Sebeok, 350-377. Cambridge, MA: M.I.T. Press.

Jaworski, Adam, Nikolas Coupland, and Dariusz Galasinski. 2012. Metalanguage: Social and Ideological Perspectives. De Gruyter Mouton.

Jenks, Christopher, and Jerry Won Lee. 2016. "Heteroglossic Ideologies in World Englishes: An Examination of the Hong Kong Context." International Journal of Applied Linguistics 26 (3): 384-402.

Jones, Rodney H., and Neville Li. 2016. "Evidentiary Video and 'Professional Vision' in the Hong Kong Umbrella Movement." Journal of Language and Politics 15 (5): 567-588.

Karyolemou, Marilena. 1994. "Linguistic Attitudes and Metalinguistic Discourse: An Investigation in the Cypriot Press." In Themes in Greek Linguistics, ed. by Irene Philippaki-Warburton, Katerina Nicolaidis, and Maria Sifianou, 253-260. Amsterdam: John Benjamins.

Lai, Mee-Ling. 2005. "Language Attitudes of the First Postcolonial Generation in Hong Kong Secondary Schools." Language in Society 34 (3):363-388.

Lai, Mee-Ling. 2011. "Cultural Identity and Language Attitudes - Into the Second Decade of Postcolonial Hong Kong.” Journal of Multilingual and Multicultural Development 32 (3): 249-264.

Lee, Carmen. 2007a. "Text-making Practices Beyond the Classroom Context: Private Instant Messaging in Hong Kong." Computers and Composition 24 (3): 285-301.

Lee, Carmen. 2007b. "Linguistic Features of Email and ICQ Instant Messaging in Hong Kong." In The Multilingual Internet: Language, Culture and Communication Online, ed. by Brenda Danet, and Susan Herring, 185-208. New York: Oxford University Press. 
Lee, Carmen. 2013. “'My English is So Poor...so I Take Photos'. Meta-linguistic Discourse of English Online." In Discourse 2.0: Language and New Media, ed. by Deborah Tannen, and Anna Marie Trester, 72-84. Washington, DC: Georgetown University Press.

Lee, Carmen, and Dennis Chau. 2018. "Language as Pride, Love, and Hate: Archiving Emotions through Multilingual Instagram Hashtags." Discourse, Context \& Media 22: 21-29.

Lee, Paul, Clement So, and Louis Leung. 2015. "Social Media and Umbrella Movement: Insurgent Public Sphere in Formation." Chinese Journal of Communication 8 (4): 356-375.

Leung, Jasmine. 2020. "Blank Protests and 'Number Songs': How Hong Kongers are Trying to Get Around the New Security Law." The Telegraph, July 11, 2020. https://www.telegraph.co.uk/news/2020/07/11/blank-protests-number-songs-hong-kongerstrying-get-around-new/.

Li Wei. 2016. "New Chinglish and the Post-Multilingualism Challenge: Translanguaging ELF in China". Journal of English as a Lingua Franca 5(1): 1-25.

Li, Wei. 2011. "Moment Analysis and Translanguaging Space: Discursive Construction of Identities by Multilingual Chinese Youth in Britain." Journal of Pragmatics 43 (5): 12221235 .

Li, Wei, Alfred Tsang, Nick Wong, and Pedro Lok. 2020. "Kongish Daily: Researching Translanguaging Creativity and Subversiveness." International Journal of Multilingualism 17 (3): 309-335. https://doi.org/10.1080/14790718.2020.1766465.

Li, Wei., and Hua Zhu. 2019. "Tranßcripting: Playful Subversion with Chinese Characters." International Journal of Multilingualism 16 (2):145-161. https://doi.org/10.1080/14790718.2019.1575834

Lin, Angel. 1996. "Bilingualism or Linguistic Segregation? Symbolic Domination, Resistance and Code-switching in Hong Kong Schools." Linguistics and Education 8: 49-84.

Lin, Angel. 1997. “Analyzing the 'Language Problem' Discourses in Hong Kong: How Official, Academic, and Media Discourses Construct and Perpetuate Dominant Models of Language, Learning, and Education”. Journal of Pragmatics 28 (4): 427-440.

Lin, Angel. 2000. "Lively Children Trapped in an Island of Disadvantage: Verbal Play of Cantonese Working-Class Schoolboys in Hong Kong." International Journal of the Sociology of Language 143 (1): 63.

Lippi-Green, Rosina. 1997. English with an Accent. London: Routledge.

Little, Laura E. 2017. "Laughing at Censorship." Yale Journal of Law \& the Humanities 28 (2): Article 1. 
Lou, Jackie, and Adam Jaworski. 2016. "Itineraries of Protest Signage: Semiotic Landscape and the Mythologizing of the Hong Kong Umbrella Movement." Journal of Language and Politics 15 (5): 612-645.

Martín Rojo, Luisa. 2014b. "Taking over the Square.” Journal of Language and Politics 13 (4): 623-652.

Mathews, Gordon. 1997. "Hèunggóngyàhn: On the Past, Present, and Future of Hong Kong Identity." Bulletin of Concerned Asian Scholars 29 (3): 3-13.

https://doi.org/10.1080/14672715.1997.10413089.

Meng, Bingchun. 2011. "From Steamed Bun to Grass Mud Horse: E Gao as Alternative Political Discourse on the Chinese Internet." Global Media and Communication 7 (1): 33-51.

Moser, David. 2018. "Keeping the Ci in Fengci: A Brief History of the Chinese Verbal Art of Xiangsheng”. In Not Just a Laughing Matter: Interdisciplinary Approaches to Political Humor in China. ed. by King-fai Tam, and Sharon R. Wesoky, 77-95. Singapore: Springer.

Niedzielski, Nancy, and Dennis Preston. 2003. Folk Linguistics. Berlin: Mouton de Gruyter.

Palfreyman, David. 2005. "Othering in an English Language Program.” TESOL Quarterly 39 (2): 211-233. https://doi.org/10.2307/3588309.

Panovic, Ivan. 2017. "Arabic in a Time of Revolution: Sociolinguistic Notes from Egypt”. In Media in the Middle East: Activism, Politics, and Culture, ed. by Nele Lenze, Charlotte Schriwer, and Zubaidah Abdul Jalil, 223-256. Cham, Switzerland: Springer.

Pennington, Martha, and Francis Yue. 1994. "English and Chinese in Hong Kong: Pre-1997 Language Attitudes." World Englishes 13 (1):1-20.

Preston, Dennis. 1996. "Whaddayaknow?: The Modes of Folk Linguistic Awareness.” Language Awareness 5 (1): 40-74.

Preston, Dennis. 2012. "Folk Metalanguage.” In Metalanguage: Social and Ideological Perspectives, ed. by Adam Jaworski, Nikolas Coupland, and Dariusz Galasinski, 75-101. Berlin: De Gruyter Mouton.

Rose, Margaret A. 1978. Reading the Young Marx and Engels: Poetry, Parody and the Censor. London: Croom Helm.

Sapountzis, Antonis, and Susan Condor. 2013. "Conspiracy Accounts as Intergroup Theories: Challenging Dominant Understandings of Social Power and Political Legitimacy." Political Psychology 34 (5): 731-52.

Sataline, Suzanne. 2014. "Occupy Central Encounters a Class Problem.” The New Yorker, October 4, 2014. https://www.newyorker.com/news/news-desk/occupy-centrals-classproblem. 
Shiri, Sonia. 2015. "Co-Constructing Dissent in the Transient Linguistic Landscape: Multilingual Protest Signs of the Tunisian Revolution". In Conflict, Exclusion and Dissent in the Linguistic Landscape, ed. by Rani Rubdy and Selim Ben Said, 239-259. London: Palgrave Macmillan.

Thomas, George. 1991. Linguistic Purism. London/New York: Longman.

Tilly, Charles. 2006. Regimes and Repertoires. Chicago: The University of Chicago Press.

Tufekci, Zeynep. 2018. Twitter and Tear Gas: The Power and Fragility of Networked Protest. New Haven: Yale University Press.

Varis, Piia. 2019. "Conspiracy Theorising Online: Memes as a Conspiracy Theory Genre.” Tilburg Papers in Culture Studies no. 238.

Varis, Piia, and Jan Blommaert. 2015. "Conviviality and Collectives on Social Media: Virality, Memes, and New Social Structures.” Multilingual Margins 2 (1): 31-45.

Vladimirou, Dimitra, and Juliane House. 2018. "Ludic Impoliteness and Globalisation on Twitter: "I Speak England Very Best" \#agglika_Tsipra, \#Tsipras \#Clinton”. Journal of Pragmatics 134: 149-62.

Vrij Aldert. 2008. "Beliefs about Nonverbal and Verbal Cues to Deception. In Detecting Lies and Deceit, ed. by Aldert Vrij, 115-140. Chirchester: Wiley.

Wang, T.-Y. 2019. "Generations, Political Attitudes and Voting Behavior in Taiwan and Hong Kong.” Electoral Studies 58: 80-83. https://doi.org/10.1016/j.electstud.2018.12.007.

Woolard, Kathryn, and Bambi Schieffelin. 1994. "Language Ideology." Annual Review of Anthropology 23 (1): 55-82.

Wozniak, Audrey M. 2015. "River-crabbed Shitizens and Missing Knives: A Sociolinguistic Analysis of Trends in Chinese Language Use Online as a Result of Censorship." Applied Linguistics Review 6 (1): 97-120. 